\title{
COMMENTS
}

\section{Arbitrating Statutory Rights in the Union Setting: Breaking the Collective Interest Problem Without Damaging Labor Relations}

\author{
Albert Y. Kim $\dagger$ \\ INTRODUCTION
}

As judicial caseloads have risen, arbitration and other forms of alternative dispute resolution have become popular, especially as methods for the resolution of employer-employee disputes. ${ }^{1}$ In an attempt to lessen litigation expenses and speed up the resolution of disputes, employers and employees have moved away from litigation and toward predispute mandatory arbitration agreements. ${ }^{2}$ With the recent expansion of statutory protection against discrimination in the workplace, discrimination claims will place even more pressure on already crowded court dockets, further intensifying the trend toward finding alternatives to litigation. ${ }^{3}$ However, despite the wide-ranging use of binding commercial arbitration, federal courts traditionally refused to enforce agreements mandating the arbitration of statutory employment dis-

† B.A. 1993, Swarthmore College; J.D. Candidate 1998, The University of Chicago.

2 See Stephen W. Skrainka, The Utility of Arbitration Agreements in Employment Manuals and Collective Bargaining Agreements for Resolving Civil Rights, Age and ADA Claims, 37 SLU L Rev 985, 992-93 (1993) (setting forth advantages of arbitration over litigation and advocating arbitration of statutory discrimination claims in the collective bargaining context).

2 Id.

3 Id at 993. 
crimination claims. ${ }^{4}$ Courts viewed such claims as too important to entrust to final arbitration. ${ }^{5}$

In the watershed case of Gilmer $v$ Interstate/Johnson Lane Corp, ${ }^{6}$ the Supreme Court punctured the judicial presumption that arbitration was an inadequate forum for statutory discrimination claims. The Court ruled that because the applicable arbitration procedures met certain due process requirements, they were an adequate substitute for litigation, even when statutory employment discrimination claims were at issue. ${ }^{7}$ Gilmer, along with previous Supreme Court decisions interpreting the Federal Arbitration Act $^{8}$ as establishing a broad presumption of arbitrability, ${ }^{9}$ gave lower courts the authority they needed to enforce predispute mandatory arbitration clauses covering Title VII, ${ }^{10}$ Age Discrimination in Employment Act ("ADEA"), ${ }^{11}$ and Americans with Disabilities Act ("ADA") ${ }^{12}$ claims. ${ }^{13}$

But while courts have enforced individual agreements to arbitrate statutory claims, they have been reluctant to do the same with respect to agreements contained in collective bargaining contracts because of the unique dangers such agreements pose to minority rights. ${ }^{14}$ For example, unlike her counterpart in the in-

4 See, for example, Alford $v$ Dean Witter Reynolds, Inc, 905 F2d 104, 105 (5th Cir 1990), vacated, 500 US 930 (1991); Utley $v$ Goldman Sachs \& Co, 883 F2d 184, 187 (1st Cir 1989).

${ }^{5}$ See, for example, Alford, 905 F2d at 106-07; Swenson $v$ Management Recruiters International, Inc, 858 F2d 1304, 1306-07 (8th Cir 1988).

6 500 US 20 (1991).

7 Id at 30-32.

${ }^{8}$ Pub L No 80-282, 61 Stat 669 (1947), codified as amended at 9 USC $\S 1$ et seq (1994).

' See Shearson/American Express, Inc $v$ McMahon, 482 US 220, 238-42 (1987) (holding that Securities Exchange Act and RICO claims are arbitrable); Mitsubishi Motors Corp $v$ Soler Chrysler-Plymouth, Inc, 473 US 614, 628-29 (1985) (establishing broad presumption of arbitrability and subjecting antitrust dispute to binding arbitration); Moses $H$. Cone Memorial Hospital v Mercury Construction Corp, 460 US 1, 24-25 (1983) (interpreting the Federal Arbitration Act to mandate that courts resolve doubts regarding arbitrability in favor of arbitration).

${ }^{10}$ Pub L No 88-352, 78 Stat 253 (1964), codified as amended at 42 USC $\S 2000$ e et seq (1994).

" Pub L No 90-202, 81 Stat 602 (1967), codified as amended at 29 USCA $\$ \S 621$ et seq (West 1985 \& Supp 1997).

${ }_{12}$ Pub L No 101-336, 104 Stat 327 (1990), codified as amended at 42 USC $\S 12101$ et . seq (1994).

${ }^{13}$ See, for example, Austin v Owens-Brockway Glass Container, Inc, 78 F3d 875, 88586 (4th Cir) (enforcing clause covering Title VII and ADA claims), cert denied, $117 \mathrm{~S} \mathrm{Ct}$ 432 (1996); Bender v A.G. Edwards \& Sons, Inc, 971 F2d 698, 700 (11th Cir 1992) (enforcing clause covering Title VII claim); Mago v Shearson Lehman Hutton, Inc, 956 F2d 932, 935 (9th Cir 1992) (enforcing clause covering Title VII claim); Crawford $v$ West Jersey Health Systems (Vorhees Division), 847 F Supp 1232, 1242 n 13 (D NJ 1994) (finding Title VII and ADEA claims arbitable).

" See, for example, Pryner v Tractor Supply Co, 109 F3d 354, 363-64 (7th Cir), cert 
dividual employment arbitration setting, the union employee cannot control the arbitration proceedings. Furthermore, a potential conflict exists between a union's duty to its members collectively and a single member's interest in seeing her claim redressed. ${ }^{15}$ This "collective interest problem" is not present in the individual arbitration context.

Circuit courts disagree about whether the potential conflict created by this collective interest problem should prevent the enforcement of mandatory labor arbitration clauses. The Fourth Circuit's recent decision in Austin v Owens-Brockway Glass Container, Inc ${ }^{16}$ leads the growing trend to enforce mandatory arbitration clauses of statutory claims. The court ruled that a mandatory arbitration clause in a collective bargaining agreement must be enforced, even with respect to Title VII and ADA claims. ${ }^{17}$ The court glossed over the collective interest problem in the union setting, focusing instead on the Gilmer presumption of arbitrability. ${ }^{18}$ The Seventh Circuit, however, disagreed with the reasoning in Austin. In its decision in Pryner $v$ Tractor Supply Co, ${ }^{19}$ the court focused on the collective interest problem in labor arbitration and held that a union could not agree to arbitrate members' statutory rights if the union controlled the grievance process.

This Comment argues that because it did not adequately address the collective interest problem-a problem of paramount concern when individual statutory discrimination rights are at stake-the Fourth Circuit reached the wrong conclusion in Aus-

denied, 118 S Ct 294 (1997); Tran v Tran, 54 F3d 115, 117-18 (2d Cir 1995), cert denied, 116 S Ct 1415 (1996); Bynes v Ahrenkiel Ship Management, (US) Inc, 944 F Supp 485, 487-88 (W D La 1996); Bush v Carrier Air Conditioning, 940 F Supp 1040, 1043-46 (E D Tex 1996); Jackson v Quanex Corp, 889 F Supp 1007, 1010-12 (E D Mich 1995); Randolph $v$ Cooper Industries, 879 F Supp 518, 520-23 (W D Pa 1994); Block v Art Iron, Inc, 866 F Supp 380, 385-87 (N D Ind 1994); Adams v Burlington Northern Railroad Co, 843 F Supp 686, 690-91 (D Kan 1994).

is See Alexander $v$ Gardner-Denver Co, 415 US 36, 58 n 19 (1974). Additionally, the labor arbitrator's approach is markedly different from that of an individual employment arbitrator. Traditionally, labor arbitrators have focused on interpreting the contractual terms of the collective bargaining agreement, deliberately ignoring public external law and thus leaving the employee free to litigate her statutory claims in court. See id at 5354. See also David E. Feller, Arbitration and the External Law Revisited, 37 SLU L Rev 973, 980 (1993) (arguing that arbitrators are not competent to apply external law); Bernard D. Meltzer, Labor Arbitration and Discrimination: The Parties' Process and the Public's Purposes, 43 U Chi L Rev 724, 728-38 (1976) (arguing that arbitrators should enforce only contractual rights by comparing that stance to two other extremes: arbitrators who directly apply the law and arbitrators who will not decide any issue also covered by external law).

${ }_{16} 78$ F3d 875 (4th Cir), cert denied, 117 S Ct 432 (1996).

${ }^{17}$ Id at 885-86.

${ }^{18}$ See id at $882 \mathrm{n} 2$.

19 109 F3d 354, 362-63 (7th Cir), cert denied, 118 S Ct 294 (1997). 
tin. In contrast, the Seventh Circuit determined that the collective interest problem present in labor arbitration was dispositive. ${ }^{20}$ However, the solution the Seventh Circuit put forth-allowing the plaintiff to pursue arbitration and a court suit simultaneously-also is unsatisfactory. This Comment argues that the mandatory labor arbitration of discrimination claims is possible and desirable both for efficiency reasons and to keep the institution of labor arbitration as the centerpiece of dispute resolution. As this Comment will explain, final and binding arbitration of statutory employment discrimination disputes should occur only when certain minimum procedural safeguards are in place and when employees can individually control the dispute settlement mechanism. ${ }^{21}$

Part I of this Comment briefly reviews the institution of labor arbitration and early judicial hostility toward arbitration of statutory claims. Part II outlines the recent trend toward accepting arbitral proceedings as an adequate substitute for courtbased litigation, even when the dispute concerns individual statutory rights. Part III discusses the important distinctions between labor arbitration through collective bargaining agreements and individual employment arbitration. It concludes that collective interest problems within the labor arbitration process render the current system unsuitable for final and binding resolution of statutory discrimination disputes. Finally, Part IV proposes a two-track labor arbitration mechanism under which individual union members would have greater freedom to control statutory discrimination claims. By implementing this procedure, employers could address judicial concerns over the collective interest problem while still going forward with binding arbitration of statutory claims.

\section{HISTORICAL BACKGROUND}

In the 1950s, the Supreme Court strongly endorsed labor arbitration. By the 1970s and the early 1980s, however, the Court developed a more suspicious attitude regarding the arbitration of statutory claims. The Court's attitude began to change back

20 Id at 362.

${ }^{21}$ While considerable commentary has addressed the relative merits of the arbitral forum and the courthouse, less has been written on enforcing mandatory arbitration agreements in collective bargaining contracts. Furthermore, courts only recently have begun looking at the possibility of modifying labor arbitration procedures to allow enforcement of such clauses. This Comment explores new territory by focusing on the collective interest problem in labor arbitration and recommending modifications to allow mandatory arbitration of statutory claims. 
again, though, in the late 1980s. The Court eventually came nearly full circle in 1991 with its decision in Gilmer to allow binding arbitration of an individual statutory discrimination claim..$^{22}$ In order to recognize the limited reach of the current judicial presumption of arbitrability, specifically that union members cannot be forced to arbitrate statutory claims, it is important to examine this evolution in the theoretical underpinnings of arbitration and the arbitration of statutory rights.

\section{A. The Broad Presumption of Labor Arbitrability}

In the late 1950s and early 1960s, the Supreme Court cemented the role of arbitration in employer-union relations with its decisions in Textile Workers Union $v$ Lincoln Mills ${ }^{23}$ and the Steelworkers cases. ${ }^{24}$ In Lincoln Mills, the Court held that Section 301 of the Labor Management Relations Act of $1947^{25}$ allowed federal courts to enforce agreements between employers and unions to arbitrate grievance disputes. ${ }^{26}$ Relying on the Act's legislative history, the Court found that an arbitration clause serves as the quid pro quo for a union's agreement not to strike, ${ }^{27}$ thus invalidating the common law rule against enforcement of arbitration agreements. ${ }^{28}$

Having established the viability of labor arbitration in Lincoln Mills, the Court strengthened the system in the Steelworkers cases. In United Steelworkers $v$ American Manufacturing $\mathrm{Co}^{29}$ the Court held that when the union and the employer have agreed to arbitrate all disputes, a court's only role is "to ascertain[ ] whether the party seeking arbitration is making a claim which on its face is governed by the contract." Any larger role would interfere with the collective bargaining agreement and reduce its "stabilizing influence" on industrial relations. ${ }^{30}$ Consequently, the Court prescribed that judges should not evaluate

22 See 500 US at 23.

${ }^{23} 353$ US 448 (1957).

${ }^{24}$ United Steelworkers v Enterprise Wheel \& Car Corp, 363 US 593 (1960); United Steelworkers $v$ Warrior \& Gulf Navigation Co, 363 US 574 (1960); United Steelworkers $v$ American Manufacturing Co, 363 US 564 (1960).

${ }_{25}$ Pub L No 80-101, 61 Stat 156 (1947), codified at 29 USC § 185 (1994).

${ }^{25}$ See 353 US at 455 .

${ }^{2}$ See id at 455-56. In Lincoln Mills, the employer denied several assignment grievances filed by the union. The union then requested arbitration, the final step in the agreed upon grievance procedures. After the employer denied the arbitration request, the union filed suit in federal court to compel arbitration. Id at 449.

${ }^{23}$ See id at 456.

${ }^{2} 363$ US 564, 567-68 (1960).

${ }^{30}$ Id at 567. 
grievances on the merits but instead should leave ultimate resolution to the arbitral panel. ${ }^{31}$ In United Steelworkers $v$ Warrior \& Gulf Navigation $\mathrm{Co}^{32}$ the Court emphasized that a collective bargaining agreement was an "effort to erect a system of industrial self-government." Accordingly, the sweep of arbitration agreements should reach broadly; all "[d]oubts should be resolved in favor of coverage. ${ }^{.33}$ Supported by these rulings, the internal dispute resolution mechanism became the centerpiece of industrial relations.

\section{B. The Exception for Statutory Discrimination Claims}

Four years after the Steelworkers cases, Congress enacted Title VII of the Civil Rights Act of $1964,{ }^{34}$ guaranteeing employees freedom from discriminatory employment practices ${ }^{35}$ In Alexander $v$ Gardner-Denver $C_{0}{ }^{36}$ the Supreme Court began a new era in labor arbitration by holding that statutory employment discrimination rights trump contractual provisions for handling disputes in a collective bargaining agreement. Specifically, the Court ruled that a union member could not be estopped from filing a Title VII suit after an adverse arbitral award. ${ }^{37}$

The Alexander Court based its ruling on statutory language, legislative intent, the role of the labor arbitrator, the conflict between the interest of the union and the individual employee, and the procedural inadequacies of arbitration. First, the Court found that both the language and legislative history of Title VII indicated that Congress sought to enact a system of overlapping remedies, with the courts as the ultimate enforcer ${ }^{38}$ According to the Alexander court, Congress viewed the rights conferred by Title VII as so important that it would violate the purpose of the statute to allow their prospective waiver. ${ }^{39}$

Second, the Court found that the role of a labor arbitrator was to interpret the collective bargaining agreement and enforce

${ }^{31}$ See id at 569 ("When the judiciary undertakes to determine the merits of a grievance under the guise of interpreting the grievance procedure of collective bargaining agreements, it usurps a function which under that regime is entrusted to the arbitration tribunal.").

\$2 363 US 574, 580 (1960).

${ }^{33}$ Id at 583.

${ }^{34}$ Pub L No 88-352, 78 Stat 253 (1964), codified as amended at 42 USC $\S 2000$ e et seq (1994).

${ }^{35} 42$ USC $\S 2000 \mathrm{e}-2(a)$.

${ }^{36} 415$ US 36, $51-52$ (1974).

${ }^{37}$ See id at 52.

${ }^{38}$ Id at $47-49$.

39 Id at 51-52. 
contractual rights, not to apply public law-traditionally considered to be the sole province of the judiciary..$^{40}$ While unions were allowed to bargain on issues of collective action such as no-strike agreements, the Court found Title VII rights to be individual in nature and therefore inappropriate subjects for collective bargaining. ${ }^{41}$ Because the union had exclusive control of the grievance process, individual interests in being free from discrimination potentially could be sacrificed for the collective good of all employees.

Finally, the Court felt that the informal nature of arbitration made it an unsuitable forum for resolving statutory claims. ${ }^{42}$ Rather than directly address arbitration's deficiencies, the Court effectively chose to remove statutory claims from the system entirely. The Court found that requiring arbitration to mirror litigation would diminish its benefits as a cheaper and faster method of dispute resolution. ${ }^{43}$ Instead, the existing grievance process could continue to resolve nonstatutory claims while litigation handled statutory disputes. ${ }^{44}$

The Court extended this dichotomy to claims under the Fair Labor Standards Act ${ }^{45}$ in Barrentine $v$ Arkansas-Best Freight System, Inc ${ }^{46}$ and Section 1983 in McDonald $v$ City of West Branch..$^{47}$ In both cases, the Court held that grievance arbitration mandated by a collective bargaining agreement did not preclude the

${ }^{40}$ Id at 52-54. There is continuing controversy over whether labor arbitrators should consider external law in adjudicating grievances. See Sara Adler, Arbitration and the Americans with Disabilities Act, 37 SLU L Rev 1005, 1014 (1993) (arguing that asking labor arbitrators to apply external law damages the perception of labor arbitrators as specialists in the law of the shop). See generally Feller, 37 SLU L Rev 973 (cited in note 15) (arguing that applying external law may result in increased judicial review, thus destroying the unique nature of labor arbitration as a substitute for industrial strife). But see Stephen L. Hayford and Anthony V. Sinicropi, The Labor Contract and External Law: Revisiting the Arbitrator's Scope of Authority, $1993 \mathrm{~J}$ Dispute Resolution 249, 277-87 (1993) (recommending that arbitrators apply external law more aggressively in order to keep labor arbitration a viable institution). This important topic deserves expanded attention, but is beyond the scope of this Comment. This Comment assumes that labor arbitrators, like employment arbitrators, may and should consider public law in their deliberations.

"1 See Alexander, 415 US at $58 \mathrm{n} 19$ ("In arbitration, as in the collective-bargaining process, the interests of the individual employee may be subordinated to the collective interests of all employees in the bargaining unit."). For instance, union representatives could decline to pursue a discrimination claim in order to stay in the employer's good graces.

${ }^{2}$ See id at 56-58. Examples of such informal procedures include arbitration's limited fact finding and lack of mandatory written opinions. Id.

43 Id at 59.

4 Id at 50, 52-54, 59-60.

452 Stat 1060 (1938), codified as amended at 29 USC $\$ \S 201$ et seq (1994).

450 US 728, 737-45 (1981).

${ }^{47} 466$ US 284, 288-92 (1984). 
employee from litigating the corresponding federal statutory claims. ${ }^{48}$

This line of cases highlights the collective interest problem between collective bargaining and statutes protecting employees' individual rights. As the Court explained, even if the employee has a valid claim, the union in good faith and without breaching its duty of fair representation can choose not to pursue the claim vigorously in order to get the best deal for all of its members. ${ }^{49}$ This collective interest problem arises because the union, not the employee, contracts with the employer. Thus, in labor arbitration, "the proceedings before, during, and after the hearing, are structured by the union and employer parties. ${ }^{350}$ The employees choose to pool their economic strength to receive collective benefits, but by doing so they accede to majority rule..$^{1}$

In the union system, therefore, there is a danger that individual interests may be subsumed for the benefit of the majority ${ }^{\mathbf{6}}$ (subject to the union's duty of fair representation). ${ }^{53}$ This result can have serious implications for union members with individual grievances. For example, the union may bar the employee from bringing his own attorney to the arbitration hearing. ${ }^{54}$ More generally, the union may choose to settle the dispute with the employer before it reaches binding arbitration..$^{55}$ Settling does not necessarily breach the union's duty of fair representation because the union holds a strong interest in preserving the arbitration machinery for nonfrivolous disputes. ${ }^{56}$

${ }^{43}$ McDonald, 466 US at 292; Barrentine, 450 US at 745.

${ }^{9}$ See Barrentine, 450 US at 742.

${ }^{50}$ Reginald Alleyne, Statutory Discrimination Claims: Rights "Waived" and Lost in the Arbitration Forum, 13 Hofstra Labor L J 381, 407 (1996).

${ }^{51}$ Garcia v Zenith Electronics Corp, 58 F3d 1171, 1175-76 (7th Cir 1995).

${ }^{62}$ See id at 1176, quoting Seymour v Olin Corp, 666 F2d 202, 208 (5th Cir 1982) (“[A] union is accorded considerable discretion in dealing with grievance matters, and it may consider the interests of all its members when deciding whether or not to press the claims of an individual employee."). See also Barrentine, $450 \mathrm{US}$ at 742 ("A union balancing individual and collective interests might validly permit some employees' statutorily granted wage and hour benefits to be sacrificed if an alternative expenditure of resources would result in increased benefits for workers in the bargaining unit as a whole.").

${ }^{53}$ See note 135 and accompanying text for a brief discussion of the union's duty of fair representation.

${ }^{54}$ See Garcia, 58 F3d at 1179-80; Castelli v Douglas Aircraft Co, 752 F2d 1480, 1483 (9th Cir 1985).

${ }^{s}$ See Cole v Burns International Security Services, 105 F3d 1465, 1478-79 (DC Cir 1997) (finding that collective bargaining agreement grievance proceedings "almost invariably mean[ ] that the union controls the presentation of the statutory issue to the arbitrator. Thus, the [Alexander] Court knew that arbitration might not be fair to the individual employee, because ... the union's interests are not necessarily the same as the employee's interests, especially with respect to a claim of employment discrimination.").

${ }^{56}$ See Vaca $v$ Sipes, 386 US 171, 191-92 (1967). See also Pryner, 109 F3d at 362 ("[T]he 
Following the Court's decision in Alexander, lower courts ruled that statutory employment discrimination suits were neither precluded by prior arbitration nor subject to a prerequisite of an arbitration hearing before the individual employee could file suit in federal court. ${ }^{57}$ For example, one First Circuit case concerned a broad mandatory arbitration clause contained in a securities industry registration application, the completion of which was required as a condition of employment. ${ }^{58}$ The First Circuit dismissed the difference between individual employment arbitration and a collective bargaining agreement grievance mechanism and focused instead on the Alexander Court's holding that Title VII gives ultimate enforcement responsibility to the courts. ${ }^{59}$ According to the First Circuit, the congressional intent behind Title VII to give plenary enforcement power to the judiciary defeated any general presumption of arbitrability stemming from the Federal Arbitration Act. ${ }^{60}$

Because of the "strong legislative intent" argument, lower courts did not address the collective interest problem inherent in labor arbitration. Alexander seemed to stand for a general prohibition on final arbitration of statutory discrimination claims, so any differences between the collective bargaining agreement and individual arbitration systems were irrelevant. In 1991, however, the Supreme Court brought these differences to the forefront of arbitration jurisprudence.

union has broad discretion as to whether or not to prosecute a grievance. It may take into account tactical and strategic factors such as its limited resources ... just as other 'prosecutors' must do, as well as its desire to maintain harmonious relations among the workers and between them and the employer."). But see Robert A. Gorman, The Gilmer Decision and the Private Arbitration of Public-Law Disputes, $1995 \mathrm{U}$ Ill L Rev 635, 675 n 128 ("[T]here was not the slightest evidence that the union [in the Alexander case] or the unions in its 'progeny' cases were any less than ardent, and the Court has given no reason to believe that unions generally have conflicting interests in collective agreement cases that raise public law issues.").

${ }^{57}$ See, for example, Utley $v$ Goldman Sachs \& Co, 883 F2d at 187 (holding that employee was not required to arbitrate before filing suit despite mandatory arbitration clause in securities registration application); Swenson v Management Recruiters International, Inc, 858 F2d 1304, 1305-07 (8th Cir 1988) (Title VII claims are not subject to arbitration despite clause in employee contract.).

ss Utley, 883 F2d at 185.

so See id at 185-87.

${ }^{\infty} \mathrm{Id}$, citing Alexander, 415 US at 45, 56. 


\section{RETURNING TO THE PRESUMPTION OF ARBITRABILITY}

A. The Gilmer Shift

In Gilmer $v$ Interstate/Johnson Lane Corp, ${ }^{61}$ the Supreme Court compelled arbitration of an ADEA claim, thus rejecting the general understanding that statutory discrimination claims could never be subject to mandatory final arbitration. The Court's holding, while consistent with its decisions in the 1980s finding mandatory arbitration of commercial statutory claims permissible, ${ }^{62}$ represented a significant shift away from the doctrine of $A l$ exander, Barrentine, and McDonald, which did not allow compulsory arbitration of individual statutory discrimination claims.

The Gilmer Court ruled that an ADEA claim was subject to compulsory arbitration as outlined in a securities industry registration application. The Court first applied a presumption of arbitrability, ${ }^{63}$ and then looked to see whether anything overcame this presumption. ${ }^{64}$ The Court found no express legislative intent in the language and history of the ADEA to prevent waiver of the right to sue. ${ }^{65}$ Additionally, the Court found no "inherent inconsistency" between the fundamental purposes of the ADEA and arbitration. ${ }^{66}$ Finally, the Court determined that the applicable New York Stock Exchange ("NYSE") arbitration rules provided sufficient procedural safeguards for the plaintiff and that arbitrators had the power to issue equitable relief. ${ }^{67}$ Consequently, the Court found that arbitration was an adequate substitute for litigation. $^{68}$

The Gilmer Court distinguished Alexander and its progeny in a number of important ways. First, Gilmer involved enforcement of an arbitration agreement, while Alexander was concerned with the preclusive effect of an arbitration award. ${ }^{69}$ Second, while the employee in Gilmer had agreed to arbitrate statutory claims, the

61 500 US 20, 23 (1991).

¿2 See Rodriguez de Quijas $v$ Shearson/American Express, Inc, 490 US 477, 481-84 (1989) (holding that a claim arising under the Securities Act of 1933 is subject to the binding arbitration clause contained in customer service agreement); Mitsubishi Motors Corp $v$ Soler Chrysler-Plymouth, Inc, 473 US 614, 628-29 (1985) (holding that Sherman Act claims are arbitrable).

" Gilmer, 500 US at 26.

a See id at 26-35. Of course, arbitration clauses in contracts may be ruled unenforceable on traditional contract grounds, such as contracts of adhesion or unconscionability. See id at 33.

${ }^{65}$ See id at 29.

${ }^{66}$ See id at 27-28.

${ }^{6}$ See id at $30-32$.

${ }^{\infty} \mathrm{Id}$.

${ }^{\infty}$ Id at 35. 
agreement in Alexander covered only contract-based disputes. ${ }^{70}$ Third, and most importantly for this Comment's analysis, because the employee in Gilmer had individually signed the registration application and maintained control of the grievance proceedings, there was no collective interest problem. ${ }^{71}$

Lower courts quickly extended Gilmer's analysis to Title VII ${ }^{72}$ and ADA claims. ${ }^{73}$ In Willis $v$ Dean Witter Reynolds, Inc, ${ }^{74}$ the Sixth Circuit quoted Gilmer extensively in finding that the Supreme Court "has rejected that Title VII precludes an arbitral forum from handling such claims if a party agrees to submit all statutory claims to arbitration." The Ninth Circuit has held that binding arbitration clauses for employment discrimination claims are enforceable as long as the employee has "knowingly agreed to submit such disputes to arbitration. ${ }^{\text {75 }}$

It should be emphasized, however, that Gilmer involved an individual arbitration contract, not a collective bargaining agreement. Courts must discern how far Gilmer went in returning the judiciary to a broad general presumption of arbitrability in the labor arbitration setting. Despite the increased enforcement of mandatory arbitration clauses in securities registrations and individual employment contracts, ${ }^{76}$ some courts have recognized that Alexander's collective interest concern still applies to the union sector. Thus, the Second Circuit has ruled that a union member does not have to exhaust his arbitration remedies before filing a Fair Labor Standards Act claim. ${ }^{77}$ The court noted the

${ }^{70}$ Id. Even if the arbitration clause in Alexander had included an agreement to arbitrate statutory claims, the collective interest problem still would exist. See notes 15 and 40 for a brief discussion on the labor arbitrator's role in resolving statutory claims.

7 Id at 35.

7 See, for example, Willis $v$ Dean Witter Reynolds, Inc, 948 F2d 305 (6th Cir 1991).

${ }^{7}$ See, for example, Gateson v ASLK-Bank, NV/CGER-Banque SA, 1995 US Dist LEXIS 9004 (S D NY 1995); Solomon v Duke University, 850 F Supp 372 (M D NC 1993).

" 948 F2d 305, 309 (6th Cir 1991).

${ }^{75}$ Prudential Insurance Company of America v Lai, 42 F3d 1299, 1305 (9th Cir 1994), cert denied, 516 US 812 (1995) (holding that since arbitration clause did not describe the types of disputes covered, no knowing waiver of statutory remedies occurred).

${ }^{75}$ In an ongoing postscript to the Gilmer decision, the National Association of Securities Dealers ("NASD") revised its registration form in the summer of 1997, removing the mandatory arbitration clause. See Susan J. McGolrick, Proposed Change in NASD's Policy Moves Debate on Mandatory Arbitration, 156 Labor Rel Rep 40, 41 (Sept 8, 1997). Pending approval of the Securities and Exchange Commission, the new policy would allow employees either to enter into individual arbitration agreements with employers or to reserve the right to file court cases for statutory discrimination claims. Id. The National Labor Relations Board and the Equal Employment Opportunity Commission ("EEOC") also have taken a stance against predispute mandatory arbitration clauses. See Donna Meredith Matthews, Note, Employment Law After Gilmer: Compulsory Arbitration of Statutory Antidiscrimination Rights, 18 Berk J Empl \& Labor L 347, 356-59 (1997).

$"$ See Tran $v$ Tran, 54 F3d 115, 117-18 (2d Cir 1995). 
collective interest problem in the union context and recognized that Gilmer expressly avoided overruling Alexander and its progeny. ${ }^{78}$

\section{B. Gilmer's Procedural Requirements}

Although the Supreme Court now has accepted that statutory discrimination claims may be arbitrated in certain instances, ${ }^{79}$ the Court also has noted that not all arbitration agreements are enforceable. Gilmer established a procedural baseline against which arbitration proceedings must be judged. ${ }^{80}$

First, there must be protections against biased arbitral panels. ${ }^{81}$ The NYSE arbitration rules at issue in Gilmer provided such protection: the arbitrators must reveal their employment histories and the parties are allowed peremptory and for cause challenges against potential arbitrators. ${ }^{82}$ In addition, the NYSE rules require arbitrators to disclose any circumstances that might lead them to issue biased decisions. ${ }^{83}$ The Gilmer Court also observed that the Federal Arbitration Act gives judges the power of reversal in the event of partiality or corruption on the part of the arbitrators. ${ }^{84}$

Second, minimal discovery procedures must be in place. ${ }^{85} \mathrm{Be}-$ cause arbitration is more streamlined than litigation, discovery procedures will not be as extensive as those set forth in the Federal Rules of Civil Procedure. ${ }^{86}$ However, the arbitrators are not bound by the Federal Rules of Evidence, and the Court concluded that this extra freedom could act as a counterweight to the reduced discovery opportunities. ${ }^{87}$

The Supreme Court rejected the contention that procedural fairness would be compromised because arbitrators often do not release written opinions. ${ }^{88}$ The employee in Gilmer claimed that a lack of written opinions hinders appellate review, prevents pub-

${ }^{73}$ See id.

${ }^{79}$ See Cole v Burns International Security Services, 105 F3d 1465, 1478 (DC Cir 1997) ("The Supreme Court now has made clear that, as a general rule, statutory claims are fully subject to binding arbitration, at least outside of the context of collective bargaining.").

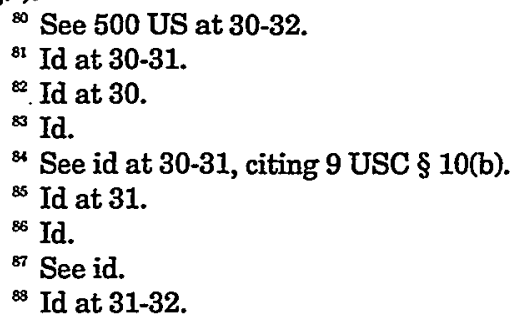


licity of the employer's discriminatory policy, and stunts the development of statutory case law. ${ }^{89}$ The Court disagreed, pointing to the NYSE rules, which require that the awards be in writing and contain the names of the parties, a summary of the issues, and a description of the award..$^{90}$ In addition, the summaries must be made available to the public. ${ }^{91}$ Finally, the NYSE arbitration rules permit the arbitrator to fashion equitable relief and do not necessarily prevent collective proceedings similar to class actions. ${ }^{92}$

The D.C. Circuit has determined that Gilmer provides a minimum level of procedural safeguards in arbitral proceedings. ${ }^{93}$ As the D.C. Circuit phrased it, protecting Title VII rights includes, "[a]t a minimum, ... . substantive protection and access to a neutral forum in which to enforce those protections. ${ }^{\text {94 }}$ In an employment arbitration situation, this involves the following requirements: neutral panels, adequate discovery, written opinions, access to all forms of relief that would be available in court, and protection from the imposition of unreasonable fees as a condition of access to the arbitral forum..$^{95}$

Id at 31 .

${ }^{\circ}$ See id at 31-32.

"Id at 32. See also Alleyne, 13 Hofstra Labor $\mathrm{L} J$ at 414 (cited in note 50). It is not clear whether the Court was requiring a written opinion or had deemed the NYSE procedure sufficient to rebut Gilmer's contention that the lack of a written opinion would lead to perverse results. Professor Alleyne claims that the Court in the cited passage was interpreting the rules as mandating a written opinion, possibly because the respondent argued in its brief that the NYSE rules required one. Id at $414 \mathrm{n} 214$. Professor Alleyne points out that, in actuality, the NYSE rules do not mandate that a written opinion lay out the rationale for the decision.

"2 Gilmer, 500 US at 32.

${ }^{2}$ See Cole, 105 F3d at 1482. Some commentators have criticized the Supreme Court's conclusion that the NYSE rules provided sufficient due process for the plaintiff in Gilmer. See Gorman, $1995 \mathrm{U}$ Ill L Rev at 661 (cited in note 56) ("The Court. . . appears to be saying [about the limited discovery rules], somewhat cold-bloodedly, that an aggrieved employee must be prepared to suffer litigative injustice as a price of efficiency."); Megan L. Dunphy, Comment, Mandatory Arbitration: Stripping Securities Industry Employees of Their Civil Rights, 44 Cath U L Rev 1169 (1995) (criticizing the use of commercial arbitration rules in the public law employment discrimination context).

On a broader level, despite the Court's point by point analysis of the NYSE arbitration procedures, it is unclear whether the Court was stating that similar rules would be required to guarantee due process or that it was possible that something less than the NYSE standards also would be sufficient. This Comment assumes that the Gilmer Court outlined minimal procedural requirements necessary for court enforcement of an arbitral award.

Th Cole, 105 F3d at 1482.

${ }^{\infty}$ Id. 


\section{LABOR VERSUS EMPLOYMENT ARBITRATION}

Although Gilmer may have set up similar basic procedural requirements for individual employment and collective bargaining agreement arbitration, the parties' incentives differ in the two contexts. In the individual employment context, the arbitration agreement is between the employer and the employee. In the collective bargaining setting, it is the union, and not the individual employee, who stands opposite the employer at the bargaining table. This distinction is crucial in assessing mandatory labor arbitration agreements, from both a legal and a policy perspective. The collective interest problem is only found in arbitration evolving out of collective bargaining agreements, where the union has control of the grievance process and hence the power to curtail an individual's statutory rights for the collective good of its membership.

\section{A. The Collective Interest Problem}

As explained in the Steelworkers cases, the traditional rationale for labor arbitration as an institution is that it is a "substitute for industrial strife. ${ }^{996}$ Collective bargaining agreements and the corresponding grievance machinery operate, therefore, as a "system of industrial self-government." In contrast, the rationale behind commercial and employment arbitration is that it serves as a cheaper, more efficient substitute for litigation..$^{98}$ Of course, neither of these rationales are rigid, and the justifications for labor and employment arbitration overlap to some degree. ${ }^{99}$

${ }^{96} 363$ US at 578.

${ }^{97}$ Id at 580. Professor Stone carries the self-government metaphor further in her description of the industrial pluralism model of collective bargaining. Katherine Van Wezel Stone, The Legacy of Industrial Pluralism: The Tension Between Individual Employment Rights and the New Deal Collective Bargaining System, 59 U Chi L Rev 575, 622-24 (1992). In this private "mini-democracy," there are "branches" corresponding to a working constitutional democracy: the collective bargaining negotiations (legislature), management (executive), and private arbitration (judiciary). Id at 623 . The self-contained ideal of the mini-government strongly suggests that the outside judiciary should not intervene and that external law should play a very small role in the world of collective bargaining dispute resolution. Id at 623-24.

${ }^{98}$ See, for example, Cole, 105 F3d at 1473 ( ${ }^{4}$ Arbitration of statutory claims [outside the context of a collective bargaining agreement] is ... mostly an attempt to reduce the burdens and expenses of formal litigation."). See also Warrior \& Gulf Navigation Co, 363 US at 578 ("In the commercial case, arbitration is the substitute for litigation.").

${ }^{9}$ See Frank Elkouri and Edna Asper Elkouri, How Arbitration Works 11 (BNA 4th ed 1985), quoting Harry Shulman, Reason, Contract, and Law in Labor Relations, 68 Harv L Rev 999, 1024 (1955) ("[Labor arbitration] is designed to aid management in its quest for efficiency, to assist union leadership in its participation in the enterprise, and to secure justice for the employees."). See also American Manufacturing Co, 363 US at 568 ("The processing of even frivolous claims may have therapeutic values."). 
Nevertheless, the two models-industrial self-government or an efficient substitute-do help to explain procedural and substantive differences between the two types of arbitration. Parties to individual employment arbitration are much less concerned about maintaining a long-term, institutional relationship than are their union counterparts, for whom developing the relationship is the purpose of the institution.

While Gilmer erased many of the general judicial suspicions about arbitration as an adequate forum for resolving statutory employment discrimination claims, the collective interest problem inherent in labor arbitration still exists as a relevant factor. ${ }^{100}$ In Gilmer, the plaintiff was an actual party to the arbitration agreement. In the union setting, however, the union, not the employee, contracts with the employer. Indeed, the Gilmer Court was careful to point out that the "tension between collective representation and individual statutory rights" relied upon in Alexander and its progeny was absent in the Gilmer individual employment arbitration setting. ${ }^{101}$ In a more recent decision, the Supreme Court reiterated that Gilmer and Alexander are consistent because of the distinction between labor and employment arbitration. ${ }^{102}$

\section{B. The Current State of the Law: Discord in Interpreting Gilmer}

Alexander's continuing application to collective bargaining agreements was challenged by the Fourth Circuit in Austin $v$ Owens-Brockway Glass Container, Inc, ${ }^{103}$ in which the court ruled that an employee's failure to arbitrate her Title VII and ADA claims as specified by a collective bargaining agreement precluded her from filing suit in federal court. In a sense, the Fourth Circuit's opinion was a natural extension of Gilmer's permission to arbitrate statutory discrimination claims. Following Gilmer, the court placed the burden on the employee to show that Congress did not intend to allow arbitration of Title VII and ADA claims and concluded that she had failed to carry that burden. ${ }^{104}$

The Austin case shared elements of both Alexander and Gilmer. Nevertheless, the Fourth Circuit downplayed Alexander's

${ }^{100}$ See 500 US at 35.

${ }^{101}$ Id.

${ }^{102}$ See Livadas $v$ Bradshaw, 512 US 107, 127 n 21 (1994) (distinguishing Gilmer from Alexander partly on the basis that in the collective bargaining context individual interests can be subordinated to collective interests).

${ }^{103} 78$ F3d 875, 885-86 (4th Cir), cert denied, 117 S Ct 432 (1996).

${ }^{104}$ See id at $880-82$. 
collective interest problem and focused instead on Gilmer's broad presumption of final and binding arbitration of statutory claims. ${ }^{105}$ Like Gilmer, Austin involved enforcement of an arbitration clause rather than the claim preclusive effects of an arbitration decision. ${ }^{106}$ As in Alexander, the clause was contained in a collective bargaining agreement, but the court emphasized that the employee was "a party to a voluntary agreement to submit statutory claims to arbitration. ${ }^{\$ 107}$ Additionally, the court decided not to differentiate between a union bargaining away the right to strike and a union bargaining for the right to arbitrate. ${ }^{108} \mathrm{Be}-$ cause the employee had agreed to arbitrate all disputes-including statutory claims-through her union's collective bargaining agreement, the court concluded that the tension between collective representation and statutory rights was minimal. ${ }^{109}$

Since Austin, courts have reached different conclusions on this issue. In Jessie $v$ Carter Health Care Center, Inc, ${ }^{110}$ a Ken'tucky district court cited Austin approvingly in precluding a Title VII and ADA suit from going forward after an employee failed to arbitrate according to the terms of her union's collective bargaining agreement. The court reasoned that, post-Gilmer, arbitration can be seen as an adequate substitute for litigation. Because the union and the employee had voluntarily agreed to the mandatory arbitration clause, it was enforceable. ${ }^{111}$

In Bush v Carrier Air Conditioning, ${ }^{112}$ however, a Texas district court expressly rejected the Austin court's reasoning and held that Alexander, not Gilmer, applied to the collective bargaining context. Because the union had exclusive control over the

${ }^{105}$ See id at 882 n 2 . The Austin court rejected what it termed the "old law," represented by Alexander, that statutory claims could not be the subject of mandatory arbitration. Id at 882 .

${ }^{106}$ See id"at 885-86.

${ }^{107}$ Id at 885.

${ }^{108}$ See id.

${ }^{109}$ See id at $882 \mathrm{n} 2$ ("Miss Austin is a party to a voluntary agreement which has explicitly agreed to the arbitration of her statutory complaints."). The court's use of the word "voluntary" is misleading in the collective bargaining context. It is the union and the employer who produce the collective bargaining agreement, not the employee and the employer. And, as the collective bargaining agreement in Austin specified, in case of a grievance, "the Company will meet with the Local Union, and both parties will have sufficient opportunity to express their opinions regarding an anticipated action." Id at 879, quoting Article 38 of the collective bargaining agreement. The employee's action was only "voluntary" in the sense that she was a member of the union. Union members surely had to accept the collective bargaining agreement as a package, including the provision ceding control of the grievance process to union representatives.

${ }^{110} 930$ F Supp 1174, 1176 (E D Ky 1996).

"in Id at 1176-77.

${ }^{12} 940$ F Supp 1040, 1045-46 (E D Tex 1996). 
arbitration, the court emphasized that employees faced the danger of having no forum in which to raise their Title VII claims. ${ }^{113}$

Highlighting this disagreement among the courts, the Seventh Circuit in Pryner $v$ Tractor Supply $\mathrm{Co}^{114}$ pointed to the "conflict between majority and minority rights" and held that mandatory arbitration of statutory claims is impermissible when the union controls the grievance proceedings. Even if the unions themselves did not commit actionable discrimination, the court feared that they might not push as vigorously against the employer as would an injured member. ${ }^{115}$ Giving control of the grievance process to the union, the court wrote, "delivers the enforcement of [minority rights] into the hands of the majority."116

The Seventh Circuit's holding in Pryner is more consistent with Supreme Court precedent than that of the Fourth Circuit in Austin. The Austin court's decision to compel arbitration of an employee's statutory discrimination claims cannot be reconciled with the Supreme Court's recognition of the collective interest problem. The Fourth Circuit's summary disposition of this tension in a two-sentence footnote is ultimately unsatisfying. ${ }^{117}$ While acknowledging that the case involved a collective bargaining agreement and that "there may be concern for . . . tension between collective representation and statutory rights, ${ }^{\text {118 }}$ the court concluded that the employee's explicit and voluntary agreement to arbitrate her statutory complaints overcame that tension. ${ }^{119}$

The Austin court's reading of the arbitration clause to cover statutory claims ignores the possibility that such a broad scope is impermissible in the first place. As the Supreme Court has indicated, the Alexander collective interest concern remains a legitimate one. ${ }^{120}$ Thus, a union's agreement to arbitrate statutory claims cannot be enforced against its individual members. The

${ }^{13}$ See id at 1045.

114 109 F3d 354, 362-63 (7th Cir), cert denied, 118 S Ct 294 (1997).

${ }^{115}$ See id.

${ }^{116}$ Id at 363. The Pryner court read the Austin decision as standing for the proposition that a post-dispute agreement to arbitrate is enforceable. Id. Although the exact chronology of events is not clear, it appears that the employee in Austin filed her Title VII and ADA complaints with the EEOC after the collective bargaining agreement went into effect. Austin v Owens-Brockway Glass Container, Inc, 844 F Supp 1103, 1106-07 (W D Va 1994). Thus, the Austin agreement appears to be a union-negotiated predispute arbitration clause. The Eleventh Circuit later interpreted Austin and Pryner as standing for opposite conclusions, solidifying the circuit split. See Brisentine $v$ Stone \& Webster Engineering Corp, 117 F3d 519, 526 (11th Cir 1997).

${ }^{117}$ See Austin, 78 F3d at 882 n 2.

${ }^{118}$ Id.

${ }^{119}$ See id.

${ }^{120}$ See note 102 and accompanying text. 
Austin dissent follows this reasoning, stating that the employee should be free to pursue arbitration (her contractual remedy) or litigation in federal court (her statutory remedy), or both. ${ }^{121}$

In Pryner, the Seventh Circuit accurately captured the continuing Supreme Court concern over collective interest problems in labor arbitration. The court allowed a union member's Title VII claims to go forward in court, even though arbitration was still pending. ${ }^{122}$ The key issue was that the dispute settlement machinery permitted only the union, and not the individual employee, to invoke arbitration. ${ }^{123}$

The Seventh and Fourth Circuits do not differ on the general presumption of arbitrability for statutory discrimination claims. ${ }^{124}$ Nor would either court refuse to enforce a post-dispute agreement by a union member to arbitrate her statutory claim. ${ }^{125}$ What divides the courts is the requisite degree of control each requires the individual employee to hold over the signing of the arbitration clause and the eventual submission of the claim to arbitration. In both cases, the union signed the arbitration clause and also controlled the dispute process. ${ }^{126}$ Only the Seventh Circuit found this level of majority control over individual rights unacceptable. ${ }^{127}$

Following the Pryner opinion, other circuits have ruled on the arbitrability of statutory discrimination claims in the union setting. In Harrison $v$ Eddy Potash, Inc ${ }^{128}$ the Tenth Circuit held that a union member did not have to follow a specified grievance procedure before filing a Title VII claim in federal court. Following the reasoning in Alexander, the court concluded that the collective bargaining agreement at issue covered only contractual, not statutory rights, and rejected the Fourth Circuit's reasoning in Austin. ${ }^{129}$ Similarly, the Eleventh Circuit in Brisentine v Stone

\footnotetext{
${ }^{122}$ See Austin, 78 F3d at 887 (Hall dissenting). See also Martin H. Malin, Arbitrating Statutory Employment Claims in the Aftermath of Gilmer, 40 SLU L Rev 77, 87 (1996) ('The union's grant of exclusive representative status is key to the development of this private self-regulating system. It also renders any suggestion that Austin voluntarily waived her statutory right to litigate her Title VII and ADA claims simply absurd.").

${ }^{122}$ See Pryner, 109 F3d at 365.

${ }^{123}$ Id at 362-63. The court commented that post-dispute agreements to arbitrate statutory claims would be allowed as long as the worker agreed and the collective bargaining agreement did not preclude such an arrangement. Id at 363 . As mentioned in note 116, the court interpreted the Austin decision to stand for this proposition.

${ }^{124}$ See Pryner, 109 F3d at 363-64; Austin, 78 F3d at 880-81.

${ }^{125}$ See Pryner, 109 F3d at 363; Austin, 78 F3d at 880-82.

${ }^{126}$ See Pryner, 109 F3d at 355-56; Austin, 78 F3d at 877-80.

${ }^{127}$ See Pryner, 109 F3d at 362-63.

${ }^{123} 112$ F3d 1437, 1453-54 (10th Cir 1997).

${ }^{129}$ See id.
} 
\& Webster Engineering Corp ${ }^{130}$ held that a fired union member did not have to file a grievance as outlined by his collective bargaining agreement before filing an ADA suit. The court expressly rejected the Austin analysis, stating that Alexander was still good law for arbitration clauses contained in collective bargaining agreements. ${ }^{131}$

In a recent Third Circuit case, Martin v Dana Corp, ${ }^{132}$ the court affirmed the dismissal of a Title VII suit because the union member did not first pursue mandatory arbitration of the claim. The court concluded that there was no collective interest problem because under the collective bargaining agreement, an individual union member could compel arbitration and would not have to rely on the union to pursue his claim. ${ }^{133}$ The Third Circuit's current stance on the issue is unclear since the Martin opinion has been vacated for rehearing en banc. ${ }^{134}$

\section{Other Procedural and Substantive Differences}

Although the collective interest problem is perhaps the critical distinction between labor and employment arbitration, other differences also exist, differences that favor allowing mandatory arbitration of statutory rights in the union context. For example, the union has a duty of fair representation that is absent in the individual employment setting. The union breaches this duty if "its actions are either arbitrary, discriminatory, or in bad faith. ${ }^{\text {135 }}$

One obvious advantage of labor arbitration is that the union is familiar with the arbitration process. Unions and employers have a great deal of experience with collective bargaining and dispute arbitration, which helps them avoid mistakes that an in-

${ }^{130} 117$ F3d 519, 526 (11th Cir 1997).

${ }^{131}$ See id at 526-27.

1997 WL 313054 (3d Cir 1997), vacated for rehearing en banc, 114 F3d 421 (3d Cir 1997).

1997 WL 313054 at *8.

${ }^{13} 114$ F3d at 421.

${ }^{135}$ Air Line Pilots Association, International v O'Neill, 499 US 65, 67 (1991), citing Vaca $v$ Sipes, 386 US 171, 190 (1967). One commentator has argued that the duty of fair representation, together with other advantages provided by the union's presence in the arbitration, is sufficient to guarantee full statutory protection for members who are victims of employer discrimination. See Robert A. Ringler, Gilmer and Compulsory Arbitration of Employment Claims in the Union Sector: Avoiding a "Distinction without a Difference", 47 Labor L J 147, 157-58 (1996). However, the Alexander Court noted that a breach of this duty can be difficult to establish, especially since there is a danger that the union itself may have discriminatory practices. See 415 US at 58 n 19 (noting that Title VII applies to unions as well as employers). 
dividual employee might make. ${ }^{136}$ The union also can correct deficiencies in the grievance system during the next collective bargaining round. ${ }^{137}$ The arbitrator selection process also may favor unions over individual employees. Collective bargaining agreements often provide for a joint selection process between unions and employers. ${ }^{138}$ This mutual selection system provides each party with veto power over the other's choice of arbitrator. ${ }^{139} \mathrm{Se}$ curities arbitration procedures also provide a joint selection process, ${ }^{140}$ but because unions are repeat players in arbitration (unlike individual employee complainants), they may have more expertise in selecting arbitrators. Moreover, there may be less reason to fear arbitrator bias since unions will be able to identify and veto arbitrators who systematically rule for employers. ${ }^{141}$

Unions also are likely to have greater bargaining power than individual employees. At least one commentator, however, has recommended enforcing mandatory arbitration agreements in the union context for precisely this reason. ${ }^{142}$ In the nonunion context, the employees may be presented with an arbitration agreement on a take-it-or-leave-it basis as a condition of employment. ${ }^{143}$ Thus, the employers may be able to "structure arbitration in ways that may systematically disadvantage employees."144

Given the possibly greater protections that union employees may have in the arbitral process, a balancing test to determine when mandatory arbitration clauses should be enforced has a certain allure. But the Supreme Court has not approved the use of a balancing test for determining when mandatory arbitration clauses should be enforced. ${ }^{145}$ Nor should it do so. Union control of the grievance process and the collective interest problem that

\footnotetext{
${ }^{136}$ See Jeanette A. Davy and George W. Bohlander, Recent Findings and Practices in Grievance-Arbitration Procedures, 43 Labor L J 184, 184 (1992) (citing Bureau of National Affairs study that found grievance resolution provisions in 99 percent of sampled collective bargaining agreements).

${ }^{137}$ See Ringler, 47 Labor L J at 159 (cited in note 135).

${ }^{138}$ See Elkouri and Elkouri, How Arbitration Works at 135 (cited in note 99).

${ }^{139}$ See Alleyne, 13 Hofstra Labor L J at 408-09 (cited in note 50).

${ }^{110}$ General Accounting Office ("GAO"), Employment Discrimination, How Registered Representatives Fare in Discrimination Disputes 5-6 (1994).

${ }^{14}$ See Ringler, 47 Labor $L J$ at 159 (cited in note 135).

${ }^{142}$ See Walter C. Brauer, III, Public Law and Arbitration, 43 Labor L J 547, 548-49 (1992).

${ }^{163}$ The Supreme Court in Gilmer noted in dicta that inequality in bargaining power between employers and employees is not a sufficient reason to hold that arbitration agreements are never enforceable in the employment context." 500 US at 33. However, the Court did leave open the possibility that the agreements could be unenforceable on traditional unconscionability grounds. See id.

${ }^{14}$ Cole, 105 F3d at 1477.

${ }^{145}$ See Section III.A.
} 
such control generates is still the dominant issue in the Court's analysis of collective bargaining agreements and statutory rights dispute resolution. ${ }^{146} \mathrm{As}$ long as individual union members cannot control the fate of their complaint, statutory discrimination protection coverage will be incomplete. Arbitral due process safeguards are meaningless if the injured party cannot reach the forum in the first place.

\section{IV. "FIXING" LABOR ARBITRATION PROCEDURES}

In light of the minimal procedural safeguards required in Gilmer and the judicial concern over the collective interest problem, it might appear impossible to modify existing labor arbitration procedures so as to allow final and binding arbitration of statutory employment discrimination claims. Perhaps a union agreement mandating arbitration of members' statutory claims will never provide sufficient protection for individual rights. Alternatively, an agreement sufficiently protective of those rights might alter the institution of labor arbitration so that it fails to fulfill its role as a substitute for industrial strife.

There are at least three proposals that attempt to redress the two concerns presented above. First, courts could force employees to exhaust the arbitration procedures for all claims, both statutory and contractual, but then subject the statutory decisions to increased judicial scrutiny. Second, courts could allow union members to pursue both litigation and an arbitration hearing of their statutory claims at the same time. However, this Comment argues that, while these two proposals adequately address the collective interest problem, only a third solution ensures that labor arbitration will continue to be the cornerstone of industrial relations. This third solution proposes that unions and employers create a separate process (or track) for statutory claims within the existing labor arbitration process. The addition of this track would satisfy Gilmer's procedural requirements and give complainants greater control of the grievance machinery. With individuals' rights protected by this two-track system, courts could then permit final and binding resolutions of statutory claims to be reached in arbitration, thus preserving labor arbitration's traditional autonomy. Before describing this two-track proposal in more detail, this Section discusses and criticizes the proposals advocated by previous commentary. 


\section{A. Increasing Judicial Scrutiny}

Some commentators have recommended that courts allow labor arbitration of statutory claims but then subject the decisions to increased judicial scrutiny (rather than the traditional limited review). ${ }^{147}$ The key concern for these commentators is that arbitrators may misapply legal concepts in coming to a final, unappealable decision. ${ }^{148}$ Their proposal would allow courts greater discretion to reexamine disputes on the merits than that granted by the current "manifest disregard" for public law doctrine. Under this doctrine, courts may only vacate arbitration awards reached through an egregious misapplication of public law. ${ }^{149}$ In short, increased judicial scrutiny of arbitration decisions could allay concerns that arbitration is an inadequate forum for redressing statutory discrimination claims.

The problem with increased judicial review is that it asks for too much in the wrong area. The Supreme Court already has ruled that arbitration can be an appropriate forum for resolving statutory claims. ${ }^{150}$ Once parties establish a neutral forum with the needed procedural safeguards, Gilmer demands that arbitration be allowed to go forward. Parties then would be precluded from filing the same claim in court but would be allowed judicial review of the award under the "manifest disregard" standard.

More fundamentally, increased judicial scrutiny will not resolve the access problem created by the union's control of the grievance procedure. Judicial review of an arbitral decision cannot address the situation in which the union quashes an individual's complaint for the collective good of the membership. With no arbitral decision to review, the court is powerless to rectify the situation-hardly an adequate solution for the injured employee.

\section{B. Allowing the Complainant to Litigate Statutory Claims}

The Seventh Circuit in Pryner allowed, and the Austin dissent would have allowed, the union member to file a statutory discrimination suit irrespective of whether she had complied with the grievance procedures provided in the collective bargaining agreement. ${ }^{151}$ Because this procedure does not require the em-

\footnotetext{
${ }^{147}$ See, for example, Mark Berger, Can Employment Law Arbitration Work?, 61 UMKC L Rev 693, 718-19 (1993).

${ }^{148}$ See Harvey S. Mars, An Overview of Title I of the Americans with Disabilities Act and Its Impact Upon Federal Labor Law, 12 Hofstra Labor L J 251, 317 (1995).

${ }^{149}$ See Wilko v Swan, 346 US 427, 436 (1953).

${ }^{150}$ See Section II.

${ }^{151}$ See Pryner, 109 F3d at 365; Austin 78 F3d at 886-87 (Hall dissenting).
} 
ployee to exhaust arbitration remedies, it eliminates the access problem created by union control of the grievance mechanisms.

There are, however, two key problems with this strategy. First, while a separate action brought in court certainly would dispose of the collective interest problem, it would also add another layer to the entire dispute resolution process. Not only would employers and unions fail to capture any efficiencies from arbitrating disputes, but allowing the employee two swings at his claim creates the possibility of two different outcomes.

Second, employees may choose to forgo the grievance process entirely, thereby damaging an integral component of the employer-union relationship. If neither employers nor unions can rely on the agreed upon grievance procedures to settle many claims, the foundation of labor relations may be irreparably harmed.

\section{Allowing Final Arbitration Through the Two-Track System}

There exists a way to solve the collective interest problem while taking advantage of the efficiency benefits of the arbitral forum. Individuals should be given greater control of the grievance proceedings when statutory employment discrimination rights are at stake. Furthermore, in such cases, the arbitral forum should observe the Gilmer procedural protections. ${ }^{152}$ As a corollary, once greater control and procedural safeguards are in place, courts should continue to review the decisions of arbitral panels with extreme deference, only reversing a decision if the arbitrator egregiously misapplied public law, and should refuse to allow repetitive litigation of the claims.

If the proposed two-track system is to afford sufficient protection to individual rights, certain inadequacies of labor arbitration must be rectified in order to meet the Gilmer standard. Thus for statutory discrimination disputes, an arbitration clause within a collective bargaining agreement should incorporate the Gilmer procedural minimums as well as provide for retaining of counsel at the hearing. Currently, a union complainant may not be entitled to representation by her own attorney in arbitration hearings. ${ }^{153}$ In fact, many times the union itself does not have an attorney present at the hearings, preferring instead to use business agents (often non-lawyers) to handle the grievances. ${ }^{154} \mathrm{By}$

${ }^{152}$ See Section II.B.

${ }^{153}$ See Garcia v Zenith Electronics Corp, 58 F3d 1171, 1179-80 (7th Cir 1995).

${ }^{15}$ G. Richard Shell, ERISA and Other Federal Employment Statutes: When is Commercial Arbitration an "Adequate Substitute" for the Courts?, 68 Tex L Rev 509, 520 n 59 
contrast, according to the NYSE rules, individual employees can appear with their own lawyer and control their own strategy and tactics. ${ }^{155}$ In addition to merely being present, the complainant's attorney should be allowed to make oral and written arguments to the arbitral panel.

Finally, the employee raising statutory rights claims should be allowed to take the matter to arbitration regardless of the union's wishes. Under the current labor system, unions control access to the grievance procedures, thus making the resolution of an employee's claim subject in part to union politics. ${ }^{156}$ For statutory rights of individuals, this is unacceptable. ${ }^{157}$

From an efficiency standpoint, employers may prefer the granting of more control to individual employees during dispute resolution to the alternative of litigation. Arbitration of statutory rights disputes in the individual employment setting caught on because it was streamlined, thus making it cheaper and faster than litigation. ${ }^{158}$ Employers enjoyed the cost savings, and employees realized that many disputes, which because of potentially low damage awards or high attorney's fees previously would never see the inside of a courtroom, could now be addressed in arbitration. ${ }^{159}$ The proposed two-track system would preserve these advantages, which are the essence of arbitration.

(1990).

${ }^{155}$ Alleyne, 13 Hofstra Labor L J at 407 (cited in note 50), citing 2 NYSE Guide (CCH) $\S \S 2600-38$ at $4311-30$ (1995).

${ }^{156}$ Professor Shell notes that the rate at which grievances reach the final stage of arbitration is related to the quality of the relationship between the union and the employer. If there are current problems, almost all grievances end up in arbitration. See Shell, 68 Tex $\mathrm{L}$ Rev at $520 \mathrm{n} 53$ (cited in note 154). See also David E. Feller, A General Theory of the Collective Bargaining Agreement, 61 Cal L Rev 663, 752-53 (1973) (commenting that political considerations within the union affect the rate of grievances carried through to arbitration).

${ }^{157}$ See Section III.C. The access problem and procedural safeguards outlined in Gilmer are the critical issues to be addressed in reforming the labor arbitration system. There remains a conflict of interest danger in choosing arbitrators, because the union and employer control the selection process, while the employee has no input in the choice. See text accompanying notes 138-42. Because securities arbitration rules allow the employee to strike prospective arbitrators for cause, union employees also should have the ability to strike arbitrators for cause in order to match the rules that the Supreme Court approved in Gilmer.

${ }^{158}$ See, for example, Robert Perkovich, Does Gilmer v. Interstate/Johnson Lane Corp. Compel the Consideration of External Law in Labor Arbitration?, 25 Stetson L Rev 53, 6667 (1995); Richard A. Bales, Compulsory Arbitration of Employment Claims: A Practical Guide to Designing and Implementing Enforceable Agreements, 47 Baylor L Rev 591, 593 (1995).

${ }^{159}$ See Bales, 47 Baylor L Rev at 593. See also Mei L. Bickner, Christine Ver Ploeg, and Charles Feigenbaum, Developments in Employment Arbitration, 52 Dispute Resolution J 8, 78-79 (Jan 1997) (summarizing employer survey results that found that most employers surveyed adopted arbitration procedures due to concerns about litigation costs). There is 
The addition of the procedural safeguards need not negate the cost savings of arbitration. The Gilmer procedural safeguards are not as extensive as those found in full-blown litigation. For example, formal discovery is a major component of trial expense, and replacing it with the reduced discovery procedures that were approved in Gilmer would save both time and money. ${ }^{160}$ Furthermore, employers can avoid the risk of large jury damage awards by going through arbitration instead of litigation. ${ }^{161}$

If the union and employer have set up the arbitration process in this manner, the union should have the power to agree to the collective bargaining agreement and bind all of its members to the agreement's terms. As long as the individual has.control of the grievance process for statutory discrimination claims, the system adequately addresses the Supreme Court's collective interest concern. Finally, if the Court did approve a two-track system, the Court would not necessarily have to overrule Alexander. Alexander now stands for the narrow proposition that the Court will not allow arbitral preclusion of statutory discrimination due to the collective interest problem found in the union setting. Since the two-track system solves the problem, mandatory and final labor arbitration of statutory claims then may go forward.

\section{Destroying Labor Arbitration?}

Even if efficiency considerations push for a two-track system with no recourse to the courts, critics may argue that the system would eviscerate labor arbitration as an institution. One of the foundations of collective bargaining is the understanding that unions not individual members should control the internal grievance process. Inserting a second track runs the risk of throwing the baby out with the bathwater, a risk that might be avoided by allowing the complainant to take the claim entirely outside of the grievance process. ${ }^{162}$ While the critics are correct in holding the

one caveat to the employer's preference for arbitration on efficiency grounds. If it turns out that employees are much more likely to file a claim in arbitration as opposed to a civil suit, increased control by individual employees may lead to greater costs for the employer.

${ }^{160}$ Terry A. Bethel, Wrongful Discharge: Litigation or Arbitration?, $1993 \mathrm{~J}$ Dispute Resolution 289, 296-97 (identifying informal discovery procedures as partial reason for relative expedience and inexpensiveness of labor arbitration when compared to litigation); Ronald Turner, Compulsory Arbitration of Employment Discrimination Claims with Special Reference to the Three A's: Access, Adjudication, and Acceptability, 31 Wake Forest L Rev 231, 285-86 (1996) ("The time and costs incurred by the employer are high where the employer responds to plaintiffs discovery in document intensive discrimination cases.").

${ }^{261}$ See Turner, 31 Wake Forest $L$ Rev at 284 (noting that recent changes in discrimination law have increased employers' vulnerability to large jury verdicts).

${ }^{162}$ In Pryner, Judge Posner stated offhandedly that the court was "given no reason to 
labor arbitration system in high esteem, a two-track system would not unduly harm the institution. It presents the better alternative for employers and unions, while ensuring adequate protection of individual employees.

The legal issue of the collective interest problem is distinct from the policy question, which asks what proposal is better for labor relations. Both of the proposed solutions to the problemallowing litigation of statutory claims and the two-track systemwould be legally satisfactory. But only the two-track system adequately addresses the labor policy concerns.

Union control of grievances is recognized by the courts as a traditional characteristic of labor arbitration. For run-of-the-mill grievances, the union member clearly does not have the right to unilaterally invoke arbitration. The Supreme Court outlined the policy rationales behind this position in Vaca $v$ Sipes, ${ }^{163}$ stating that to grant the employee an absolute right to invoke arbitration would "substantially undermine[ ]" the dispute settlement mechanism, "destroying the employer's confidence in the union's authority and returning the individual grievant to the vagaries of the independent and unsystematic negotiation." ${ }^{164}$ In addition, unchecked union members would file many more grievances, increasing costs and burdening the grievance process so as to "prevent it from functioning successfully." ${ }^{165}$ As the Court concluded, such measures would throw into doubt "whether the parties to collective bargaining agreements would long continue to provide for detailed grievance and arbitration procedures of the kind encouraged by [the Labor Management Relations Act] $\$ 203$ (d) . ...

Moreover, the Supreme Court's doctrine as expressed in Vaca predicts that, if statutory discrimination claims do comprise a large percentage of all claims, and especially if discrimination hearings generally are the most acrimonious sort of proceedings, allowing an exception to union control could lead to damaging consequences for labor relations. ${ }^{167}$ Statutory discrimination

believe that the ability of unionized workers to enforce their statutory rights outside of the grievance machinery established by collective bargaining agreements is undermining labor relations." 109 F3d at 363 . For the reasons outlined in this Comment, a closer examination of relevant policy considerations leads to the conclusion that keeping enforcement within the grievance machinery is the better alternative.

${ }^{1 \oplus} 386$ US 171, 191 (1967).

${ }^{164}$ Id.

${ }^{165} \mathrm{Id}$ at 191-92.

${ }^{165}$ Id at 192. Labor Management Relations Act $\S 203(d), 61$ Stat 153 (1947), codified at 29 USC § 173(d) (1994), reads, "[f]inal adjustment by a method agreed upon by the parties is declared to be the desirable method for settlement of grievance disputes arising over the application or interpretation of an existing collective bargaining agreement."

${ }^{167}$ See 386 US at 191-93. 
claims presently comprise a limited percentage of grievances, but that figure is likely to increase in the coming years and produce a corresponding rise in the demand for arbitrators. ${ }^{168}$ The trend is predicted because Congress only recently enacted the Civil Rights Act of 1991 and the Americans with Disabilities Act of 1990 and larger numbers of people are just now coming within the protection of the Age Discrimination in Employment Act. ${ }^{169}$ One source calculated that the number of employment discrimination cases rose by more than 2000 percent from 1970 to $1989 .{ }^{170}$ It seems likely that the wave of employment discrimination complaints in the nonunion sector will be paralleled by a similar increase within the collective bargaining context.

If this is the case, statutory employment discrimination disputes will dominate the grievance process. Allowing a member to control statutory discrimination claims could lead to the loss of union control of the dispute machinery, as well as a reduction in union bargaining power. ${ }^{171}$ The greater number of discrimination grievances taken to arbitration may create greater friction in the employer-union relationship, further endangering the collective bargaining balance.

However, despite the disadvantages of loosening union control of the grievance process, federal discrimination laws must be enforced. ${ }^{172}$ While the union's interest in preserving its relationship with the employer is strong, so is the individual employee's interest in protection from discriminatory practices. ${ }^{173}$ Moreover,

${ }^{168}$ See Walter J. Gershenfeld, New Roles for Labor Arbitrators, in Gladys W. Gruenberg, ed, Arbitration 1994, Controversy and Continuity: Proceedings of the Forty-Seventh Annual Meeting National Academy of Arbitrators 275, 278 (BNA 1994) (noting new federal legislation encouraging alternative dispute resolution and predicting a backlog of unresolved EEOC cases).

${ }^{10}$ See James A. KKing, Jr., et al, Agreeing to Disagree on EEO Disputes, 9 Labor Law 97, $97-98$ (1993). See also Bales, 47 Baylor $\mathrm{L}$ Rev at $593 \mathrm{n} 9$ (cited in note 158) ("The EEOC currently has a backlog of almost 88,000 claims, $99.5 \%$ of which it will not litigate on behalf of the claimant."), citing GAO, EEOC's Expanding Workload: Increases in Age Discrimination and Other Charges Call for New Approach 13 (1994).

${ }^{170} \mathrm{John}$ J. Donohue III and Peter Siegelman, The Changing Nature of Employment Discrimination Litigation, 43 Stan L Rev 983, 985-86 (1991) (using data obtained from the Administrative Office of the U.S. Courts).

${ }^{171}$ See Garcia $v$ Zenith Electronics Corp, 58 F3d 1171, 1176 (7th Cir 1995) (noting that even during an individual grievance procedure, the union's credibility and bargaining power are at stake).

${ }^{172}$ Alexander, 415 US at 51 ("There can be no prospective waiver of an employee's rights under Title VII . . . . Title VII's strictures are absolute and represent a congressional command that each employee be free from discriminatory practices.").

${ }^{173}$ The two interests are to some degree mutually exclusive. Professor Stone argues that while statutory individual employment rights could be seen as "perfectly compatible with the system of collective bargaining," the promise of their beneficial effect on collective bargaining has not been fulfilled and indeed, there actually may have been negative ef- 
while the danger to industrial relations caused by the predicted rise of claims is a real one, the two-track system minimizes this danger, especially when compared to litigation. After all, the question is not whether statutory claims may be adjudicated, but in which forum. If the two-track mechanism is not implemented, individual employees will continue to file claims in the already gridlocked court system, with all the drawbacks for employers and employees that litigation entails. Neither the two-track system nor available litigation will leave unions in control of the grievance. Arbitration, at least, will ease the gridlock, delay, and direct conflict between employer and employee.

This Comment has argued that courts should prefer a twotrack system as a solution to the collective interest problem in statutory discrimination. But it remains to be demonstrated that employers and unions will voluntarily adopt such a system. Employers may worry that a two-track arbitration system could collapse into a de facto single-track system. Complainants could attempt to hook their grievances onto an employment discrimination claim, thereby invoking the enhanced procedures and control.

There are two responses to this criticism. First, some disputes simply cannot be classified as statutory discrimination claims. Disagreements over job classifications, type of work performed, and an employer's decision to contract work out to nonunion employees fall into this category. ${ }^{174}$ Second, if employers do not agree to a two-track system, employees will have the right to take their statutory discrimination claims to court. Although under Title VII employees are required to petition the Equal Employment Opportunity Commission ("EEOC") before filing a statutory discrimination suit, if the EEOC does not file suit within 180 days, the employee is free to proceed to court within the next 90 days. ${ }^{175}$ Arbitration versus litigation-with all of its attendant expenses and delays-is the fundamental choice facing employers when they decide whether or not to adopt a two-track system.

It may also appear that unions would oppose giving greater control to individual members. Unions are in a different position than employers; if the dispute is litigated, they would not incur

fects. Stone, 59 U Chi L Rev at 576-77 (cited in note 97). Such negative effects emerge because federal labor law regulating collective bargaining often preempts the newly strong federal individual employment rights at the state level. Id at 593-96.

${ }^{174} I d$.

${ }^{175} 42$ USC 2000 e-5(f)(1) (1964); Turner, 31 Wake Forest L Rev at 281 (cited in note 160). 
legal expenses on behalf of individual employees. In addition, giving up any degree of control could weaken their negotiating strength in the collective bargaining process. If any statutory discrimination claim could be arbitrated at the behest of the complainant, the union would lose an important bargaining chip. Additionally, a two-track system could lessen the union's ability to regulate industrial relations and look out for the collective interest of the members as a whole.

However, like employers, unions should consider the alternatives. The Supreme Court has established that individual members must be given control of their statutory claims, either in the arbitration process or in the court system. Courts will not permit unions to return to the world in which they could settle statutory grievances before the commencement of arbitration, leaving the employee stuck with the result.

The proposed two-track modification to the grievance procedure may well be more palatable to the unions than the alternative of sending all statutory discrimination claims to the courts. First, if the employers favor a two-track mechanism in order to allow binding arbitration of statutory claims, unions likely could bargain for concessions elsewhere. Second, the unions have an interest in keeping disputes "in house" and containing grievances within the traditional labor arbitration machinery. The dispute resolution procedure contained in a collective bargaining agreement is the end product of a mutual negotiation between the unions and the employer. Although union power would be somewhat weakened because the union would not have the ability to cut short the grievance process for statutory discrimination claims, allowing complainants to circumvent internal procedures completely would undermine union control even further. Third, unions may appreciate the efficiency rationales for arbitration as a substitute for litigation, especially if disputes would be resolved more quickly. Finally, if members were given more control of statutory discrimination complaints, the union would be able to avoid a certain amount of litigation over breaches of its duty of fair representation. A two-track system would allow individual employment rights to complement collective bargaining rights, thus strengthening labor power by setting a floor for negotiations. ${ }^{176}$

${ }^{176}$ Stone, 59 U Chi L Rev at 576-77 (cited in note 97). Stone also points out that "greater individual employment rights might also remove sources of conflict within unions" since "externally imposed employment terms represent tradeoffs made by a legislature or court, rather than by unions .. . [sparing] the unions the potentially divisive effects of making such decisions themselves." Id at 577. 
In addition to the two-track system's effect on industrial relations, it boasts the added advantage of using a single procedure to resolve the discrimination claim. Under the Pryner view, ${ }^{177}$ which would allow both arbitration and litigation to proceed separately, there remains the possibility of contrary outcomes. Keeping the dispute within the confines of the arbitral system makes the arbitral decision final, thereby increasing predictability in the dispute resolution process.

It is important to keep in mind what the two-track proposal does not do. It does not require employers or unions to resort to litigation and its attendant expenses. It does not deprive the individual employee of her statutory rights. It does not give independent control of all grievances to the employee. And, given the alternatives, it does not unduly undermine the system of labor arbitration.

\section{CONCLUSION}

In order for mandatory arbitration clauses in collective bargaining agreements to be enforced for statutory discrimination claims, employers and unions must address the judicial concern over the collective interest problem. A two-track dispute settlement mechanism in which individual members possess greater control over the grievance process for statutory discrimination claims would dissipate the concern over this problem. While setting up such a system does pose some threat to the integrity of the labor dispute resolution mechanism, the alternative of separate and protracted litigation would be considerably more damaging to employer-union relations. 